Mudji Susanto, Mashudi. (2017). Tren Genetik Pertumbuhan Antarpopulasi Hibiscus macrophyllus Roxb. Ex Hornem di Jawa (Growth Trend of Hibiscus macrophyllus Roxb. Ex Hornem between Provenances in Java). Vol. 4 (1) Pp. 20-28. Doi: https://doi.org/10.23917/bioeksperimen.v4i1.3971

\title{
Tren Genetik Pertumbuhan antar Populasi Hibiscus macrophyllus Roxb. Ex Hornem di Jawa
}

\author{
Mudji Susanto*, Mashudi \\ Balai Besar Peneitian dan Pengembangan Bioteknologi dan Pemuliaan Tanaman Hutan \\ Alamat: Jl. Palagan Tentara Pelajar KM 15, Purwobinangun, Sleman, Yogyakarta \\ *Email: mudjisusanto@yahoo.com
}

\begin{abstract}
The research is to obtain trend of genetic growth of Hibiscus macrophyllus for some populations in Java Island in seedling level. The research use genetic material from 7 populations in Java Island. Design of the research was Randomized Complete Block Design to test 112 open pollinated families representing 7 provenances (populations) from Java Island (Cipatujah, Tasikmalaya; Ciguha-Pagerageng, Tasikmalaya; and Pamarican, Banjar Patroman, Ciamis; Samigaluh, Kulon Progo, Yogyakarta; Banyuasin, Purworejo, Jawa Tengah; Sumberwrigin, Bondowoso, Jawa Timur; and Senduro, Lumajang, Jawa Timur). Results of investigation showed that the growth trend of seedling of 7 populations were smililar on 0,5 month old to 2,5 months old. Individual heritability for growth or growth genetic variation were unstable (fluctuation) on 0,5 month old to 2,5 months old. The estimate of individual heritabilities of $H$. macrophyllus for growth (height) was high $\left(h^{2}{ }_{i}=0.53\right)$ on 2,5 months old in nursery. The genetic variation of growth were significant different between population and between families within population on 2,5 month old.
\end{abstract}

Keywords: trend, genetic, variation, growth, population

\begin{abstract}
Abstrak
Penelitian ditujukan untuk memperoleh tren genetik pertumbuhan Hibiscus macrophyllus dari beberapa populasi pada tingkat semai. Penelitian menggunakan materia genetik dari 7 populasi atau provenans di Pulau Jawa. Rancangan penelitian menggunakan Rancangan Acak Komplet Blok dengan menguji 112 famili perkawinan terbuka dari 7 provenans dari Pulau Jawa (Cipatujah, Tasikmalaya; Ciguha-Pagerageng, Tasikmalaya; and Pamarican, Banjar Patroman, Ciamis; Samigaluh, Kulon Progo, Yogyakarta; Banyuasin, Purworejo, Jawa Tengah; Sumberwrigin, Bondowoso, Jawa Timur; and Senduro, Lumajang, Jawa Timur). Hasil penelitian menunjukkan bahwa semua populasi yang diteliti memperlihatkan tren pertumbuhan yang hampir sama. Hertabilitas individu pertumbuhan sangat berflutuasi mulai umur 0,5 bulan sampai dengan umur 2,5 bulan. Estimasi heritabilitas indvidu untuk tinggi semai tergolong tinggi $\left(\mathrm{h}^{2}=0.53\right)$ pada umur 2,5 bulan di persemaian. Keragaman genetik pertumbuhan antar populasi maupun antar famili di dalam populasi sangat signifikan.
\end{abstract}

Kata Kunci: tren, genetik, keragaman, pertumbuhan, populasi

\section{Pendahuluan}

Tisuk (Hibiscus macrophyllus Roxb. Ex Hornem.) merupakan salah satu jenis kayu pertukangan cepat tumbuh. Sebaran alamnya meliputi Indonesia, Indochina, Malaysia, Filipina, dan India. Di Pulau Jawa tumbuh secara alami di hutan-hutan rakyat dari ketinggian $10 \mathrm{~m}$ sampai dengan $700 \mathrm{~m}$ dari permukaan laut $(\mathrm{dpl})$. Pada umur 9 tahun diameter pohonnya antara $25-30 \mathrm{~cm}$ dan tinggi pohon hingga $28 \mathrm{~m}$. Kayunya digunakan untuk bahan bangunan, kayu lapis, perabot rumah tangga, sumpit, tusuk gigi, batang koreka api, peti, perahu, dan bahan baku pulp (Wardani, 2007; Sudomo, 2013).

Permintaan kebutuhan kayu pertukangan yang terus naik pada tingkat nasional, maka jenis tersebut perlu dikembangkan. Secara nasional kebutuhan kayu pertukangan sebesar 46,3 juta $\mathrm{m}^{3} /$ tahun yaitu dari hutan alam, hutan tanaman dan hutan rakyat. Target hutan tanaman sebesar 32 juta $\mathrm{m}^{3} /$ tahun dan hutan rakyat sebesar 20 juta $\mathrm{m}^{3} /$ tahun. Untuk itu, upaya peningkatan produktivitas hutan yang tinggi sangat diperlukan. 
Untuk meningkatkan produktivitas tidak terlepas dari tiga aspek yaitu pemuliaan tanaman, manipulasi lingkungan dan perlindungan tegakan. Salah satu jenis kegiatan manipulasi lingkungan adalah melalui pengaturan jarak tanam. Sudomo (2013) menyarankan jarak tanam terbaik untuk H. macrophyllus adalah $3 \times 3 \mathrm{~m}$. Suhaendah dan Winara (2015) telah melakukan penelitian terhadap pengendalian hama pada jenis $H$. macrophyllus dengan insektisida. Pemuliaan jenis $H$. macrophyllus sebagai kayu pertukangan merupakan upaya untuk meningkatkan produktivitas hutan dalam rangka mencukupi kebutuhan kayu pertukangan.

Pemuliaan jenis $H$. macrophyllus berbasis genetik sedang dilakukan dengan beberapa kegiatan antara lain: koleksi materi genetik dari sebaran alam dari beberapa populasi hutan rakyat di Jawa, produksi bibit, pembangunan uji genetik, seleksi pohon dengan pertumbuhan terbaik dan pengembangan hasil pemuliaan.

Pemuliaan jenis $H$. macrophyllus akan berhasil jika $H$. macrophyllus mempunyai keragaman genetik yang luas, sehingga dapat diperoleh peningkatan genetik pada uji keturunan yang dibangun melalui seleksi pohon. Salah satu sifat yang akan dimuliakan dalam rangka meningkatkan riap volume adalah sifat pertumbuhan (tinggi pohon dan diameter), sehingga keragaman pertumbuhan sebagai dasar keberhasilan pemuliaan. Tujuan penelitian ini adalah mengevaluasi tingkat pertumbuhan antar populasi atau provenans di Jawa pada tingkat semai.

\section{Metodologi}

\section{Lokasi Penelitian}

Benih H. macrophyllus yang digunakan dalam penelitian berupa hasil koleksi materi genetik dari 7 populasi atau provenans di P. Jawa yang ditanam di persemaian Balai Besar Penelitian dan Pengembangan Bioteknologi dan Pemuliaan Tanaman Hutan-Yogyakarta. Koleksi materi genetik tersebut meliputi bebrapa wilayah yaitu Propinsi Jawa Barat; Propinsi Jawa Tengah; Propinsi D.I. Yogyakarta; dan Propinsi Jawa Timur Informasi lengkap mengenai asal benih yang digunakan dapat dilihat pada Tabel 1.

Tabel (Table) 1. Informasi materi genetik H. macrophyllus (Information of genetic material information of H. macrophyllus )

\begin{tabular}{|c|c|c|c|c|c|}
\hline No & Populasi/Population & $\begin{array}{l}\text { Garis Lintang/ } \\
\text { Latititue }\end{array}$ & $\begin{array}{l}\text { Garis Bujur/ } \\
\text { Longitude }\end{array}$ & $\begin{array}{c}\text { Ketinggian tempat/ } \\
\text { Altitude } \\
(\mathbf{m} \mathbf{d p l})\end{array}$ & $\begin{array}{c}\text { Jumlah Famili/ } \\
\text { Number of } \\
\text { family }\end{array}$ \\
\hline 1 & $\begin{array}{l}\text { Cipatujah-Sodong Hilir, } \\
\text { Tasikmalaya, Jawa Barat }\end{array}$ & $\begin{array}{l}7^{\circ} 30,446 \mathrm{~S} \text { sd } \\
7^{\circ} 43,450^{\prime} \mathrm{S}\end{array}$ & $\begin{array}{c}108^{\circ} 03,893^{\prime} \mathrm{E} \\
\operatorname{sd} 107^{\circ} 59,455^{\prime} \\
\mathrm{E}\end{array}$ & $10 \mathrm{sd} 518$ & 11 \\
\hline 2. & $\begin{array}{c}\text { Ciguha-Pagerageng, } \\
\text { Tasikmalaya, Jawa Barat }\end{array}$ & $7^{\circ} 05,471^{\prime} S$ & $108^{\circ} 11,847^{\prime} \mathrm{E}$ & 766 & 15 \\
\hline 3 & $\begin{array}{c}\text { Pamarican, Banjar } \\
\text { Patroman, Ciamis, Jawa } \\
\text { Barat }\end{array}$ & $7^{\circ} 24,985^{\prime} \mathrm{S}$ & $108^{\circ} 2,947^{\prime} \mathrm{E}$ & 55 & 21 \\
\hline 4 & $\begin{array}{c}\text { Banyuasin, Purworejo, } \\
\text { Jawa Tengah }\end{array}$ & $7^{\circ} 39,403 \mathrm{~S}$ & $110^{\circ} 05,381^{\prime} \mathrm{E}$ & 259 & 26 \\
\hline 5 & $\begin{array}{c}\text { Senduro, Lumajang, } \\
\text { Jawa Timur }\end{array}$ & $8002,729 ’ S$ & $113 \mathrm{o} 03,447^{\prime} \mathrm{E}$ & 912 & 9 \\
\hline 6 & $\begin{array}{c}\text { Sumberwringin, } \\
\text { Bondowoso, Jawa Timur }\end{array}$ & 7o59,422’S & $113059,5996^{\prime} \mathrm{E}$ & 789 & 6 \\
\hline 7 & $\begin{array}{c}\text { Samigaluh, Kulonprogo, } \\
\text { Yogyakarta }\end{array}$ & $7 \mathrm{o} 40,505^{\prime} \mathrm{S}$ & 110o07,954’'E & 530 & 24 \\
\hline \multicolumn{5}{|c|}{ Jumlah } & 112 \\
\hline
\end{tabular}




\section{Metode}

\section{a. Prosedur kerja}

Benih disemaikan menggunakan media campuran tanah dan pupuk kandang. Benih tersebut disemaikan dengan rancangan Randomized Complete Block Design (RCBD) dengan menguji sebanyak 112 famili dari 7 populasi; jumlah ulangan sebanyak 5 ulangan dan 5 bibit setiap famili di dalam ulangan.

\section{b. Pengukuran dan analisa data}

Pengukuran pertumbuhan tinggi bibit dilaksanakan sampai umur bibit siap ditanam di lapangan yaitu pada umur 0,5 bulan; 1 bulan; 1,5 bulan; 2 bulan dan 2,5 bulan. Pengukuran dilakukan pada semua individu bibit yang diuji dengan rancangan yang telah dibuat. Data hasil pengukuran selanjutnya di analisa pertumbuhan; heritabilitas individu; dan keragaman genetik berdasarkan umur dan data umur 2,5 bulan di analisa varian (ANOVA) dengan model linear sebagai berikut :

$$
\mathbf{Y}_{i j k}=\boldsymbol{\mu}+\mathbf{B}_{i}+\mathbf{P}_{j}+\mathbf{F}_{k(j)}+\mathbf{e}_{i j k l}
$$

$\mathrm{Y}_{i j k l m}$ : pengukuran tanaman ke $k$, populasi ke $i$, famili ke $j$ dalam populasi ke $i$

$\mu \quad$ : rerata umum

$\mathrm{B}_{i} \quad$ : pengaruh ulangan ke $i$

$\mathrm{P}_{j} \quad$ : pengaruh populasi atau provenans ke $j$

$\mathrm{F}_{k(j)}:$ pengaruh famili ke $k$ dalam populasi ke $j$

$\mathrm{e}_{i j k l}$ : sisa (error)

Perhitungan heritabilitas individu diperlukan komponen varians famili dan komponen varian lingkungan. Komponen varian diperoleh melalui analisis model campuran. Populasi diperlakukan sebagai efek tetap, sedangkan famili diperlakukan sebagai sebagai efek acak atau random (Williams et.al., 2002). Komponen-komponen varians tersebut digunakan untuk menghitung heritabilitas individu $\left(\mathrm{h}_{\mathrm{i}}^{2}\right)$. Heritabilitas individu $\left(\mathrm{h}^{2}\right)$ half-sib dihitung sebagai berikut:

$$
\begin{gathered}
h^{2}{ }_{\mathrm{i}}=\left(\sigma^{2}\right) / \sigma^{2}{ }^{\mathrm{P}} \\
\sigma^{2}{ }_{\mathrm{A}}=2.5 \mathrm{f}{ }^{2} \\
\sigma_{\mathrm{p}}^{2}=\sigma_{\mathrm{e}}^{2}+\sigma_{\mathrm{f}}^{2}
\end{gathered}
$$

Keterangan:

$\sigma_{\mathrm{A}}^{2}=$ komponen varians aditif

$\sigma_{f}^{2}=$ komponen varians famili

$\sigma^{2}=$ komponen varians fenotipik

$\sigma^{2^{\mathrm{p}}}=$ komponen varians sisa (error)

Keragaan genetik dianalisa menggunakan Koefisien Keragaman Genotip (KKG) pertumbuhan dihitung dengan rumus:

$$
\mathrm{KKG}=\frac{\sqrt{\sigma 2 g}}{\overline{\mathrm{x}}} \times 100 \%
$$

Keterangan :

$\sigma^{2} \mathrm{~g}=$ komponen varian genotip $=\sigma^{2} \mathrm{~A}$

$\sigma^{2} \mathrm{~A}=$ komponen varian aditif

$\sigma^{2} \mathrm{p}=$ komponen varian fenotipe

$\overline{\mathrm{x}} \quad=$ rerata tinggi seluruh populasi.

Kriteria nilai KKF dan KKG adalah rendah $(0 \% \leq 25 \%)$, agak rendah $(25 \% \leq$ $50 \%)$, cukup tinggi $(50 \% \leq 75 \%)$, dan tinggi $(75 \% \leq 100 \%)$.

\section{Hasil dan Pembahasan}

\section{Hasil Penelitian}

Hasil analisis tren pertumbuhan bibit $H$. macrophyllus antar populasi di persemaian mulai umur 0,5 bulan sampai umur 2,5 bulan disajikan pada Gambar 1. 


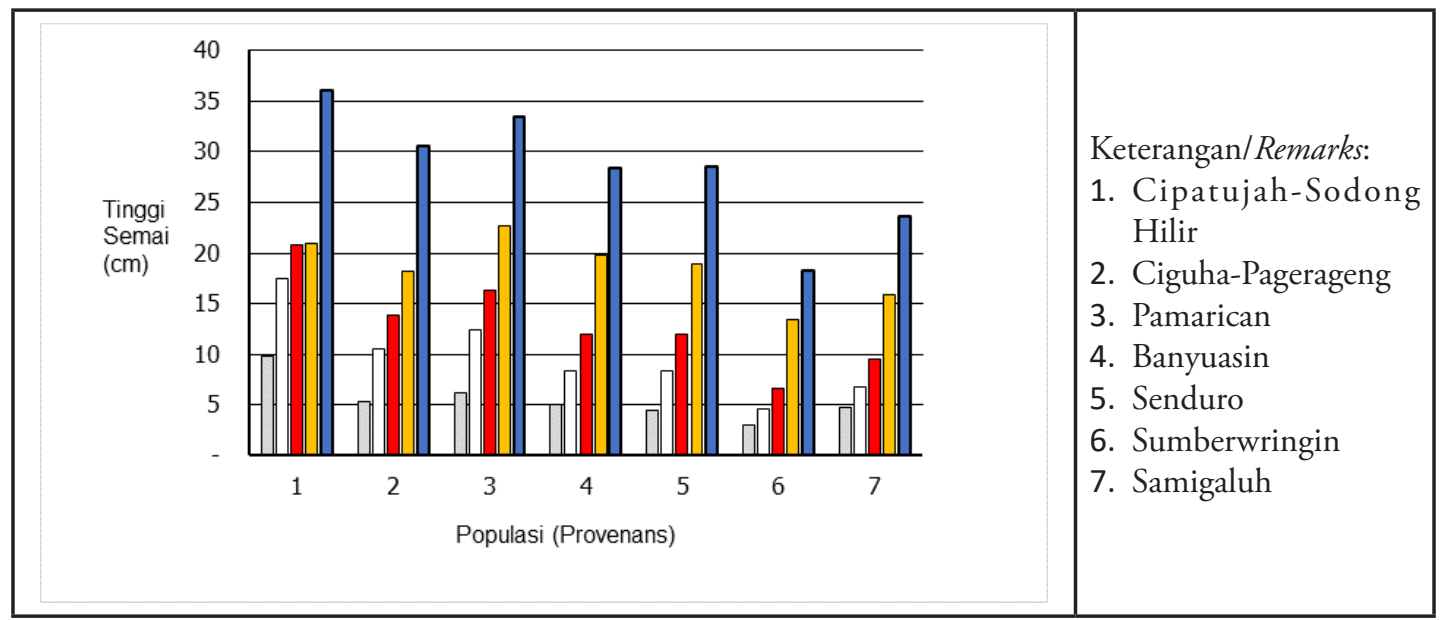

Gambar 1. Perbedaan pertumbuhan antar populasi atau provenans H. macrophyllus (Variationgrowth between populations or provenances)

Gambar 1 menunjukkan bahwa ke 7 populasi H. macrophyllus mempunyai tren pertumbuhan yang hampir sama mulai umur 0,5 bulan sampai dengan 2,5 bulan. Penambahan rerata tinggi dari umur 1,5 bulan ke umur 2,0 bulan, populasi dari Cipatujah-Sodonghilir Kabupaten Tasikmalaya, Jawa Barat tidak terlihat signifikan, sedangkan ke 6 populasi lainnya terlihat signifikan penambahan rerata tinggi bibitnya. Populasi Cipatujah-Sodong hilir mempunyai rerata tinggi pohon paling besar utuk umur 0,5 bulan; 1,0 bulan; 1,5 bulan dan 2,5 bulan, namun pada umur 2,0 bulan lebih rendah dari pada rerata tinggi populasi PamaricanBanjar. Populasi atau provenans Cipatujah-Sodong
Hilir yang paling baik pertumbuhannya dalam uji tersebut.

Hasil analisis tren pertumbuhan dari semua populasi dan tren heritabilitas individu disajikan pada (Gambar 2). Tinggi bibit $H$. macrophyllus dari semua populasi yang diuji mempunyai tren yang meningkat yang cepat, sejalan dengan pertumbuhan tinggi pohon setiap umur pengamatan akan diikuti perubahan heritabitas individu tinggi bibit. Heritabitas tinggi bibit pada umur 0,5 bulan sebesar 0,60 ; pada umur 1,0 bulan sebesar 0,71; pada umur 1,5 bulan sebesar 0,78 ; pada umur 2,0 bulan sebesar 0,54 ; dan pada umur 2,5 bulan sebesar 0,53 .

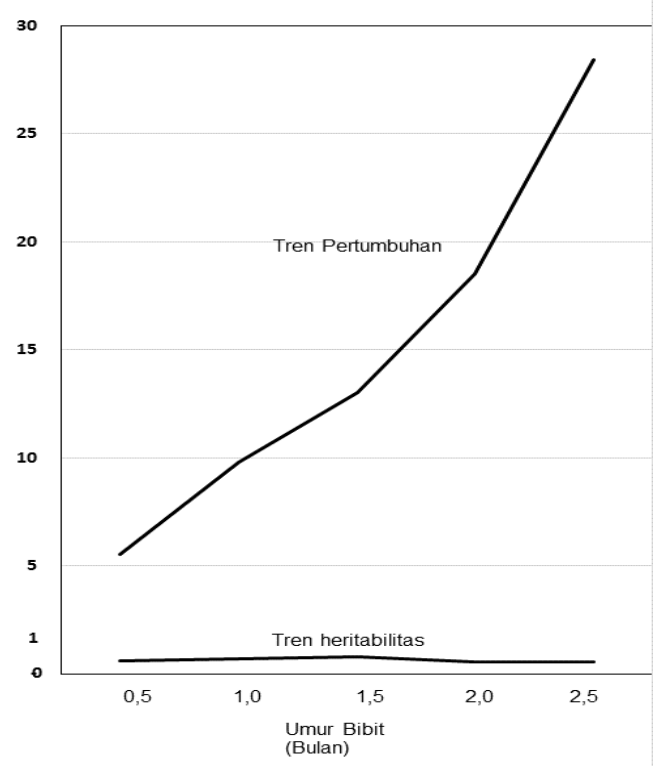

Gambar 2. Tren pertumbuhan dan heritabilitas individu pertumbuhan bibit dari semua populasi $\boldsymbol{H}$. macrophyllus yang diuji (Growth trend and individual heritability for growth in the trial) 
Hasil analisis tren keragaman genetik tinggi pada Gambar 3 dan hasil analisis varian (ANOVA) bibit H. macrophyllus dari 7 populasi disajikan disajikan pada Tabel 2.

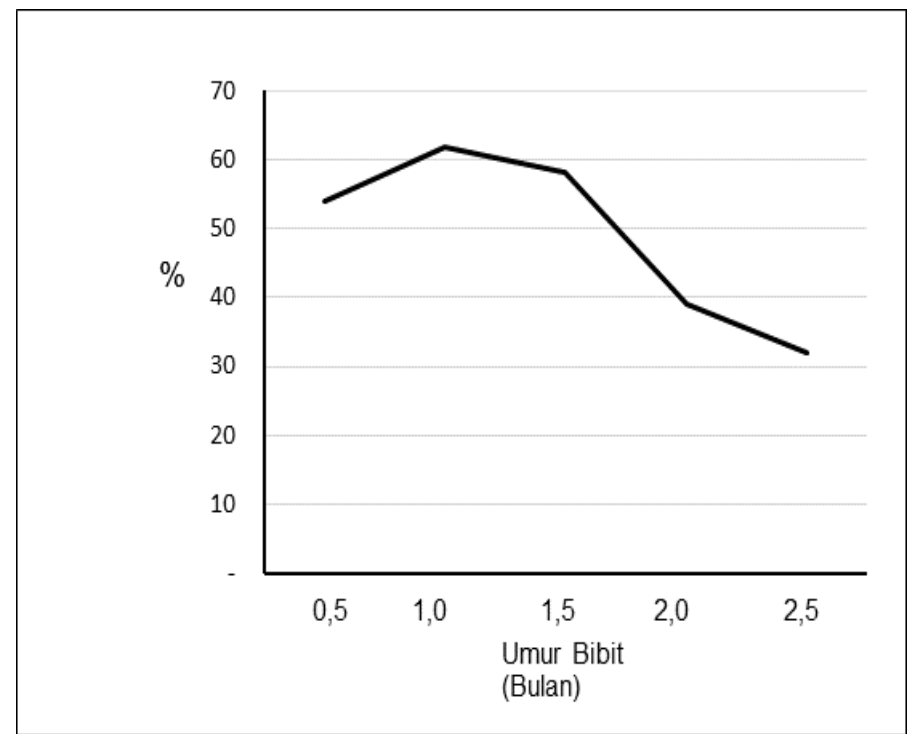

Gambar 3. Tren keragaman genetik pertumbuhan bibit $H$. macrophyllus dalam uji (Trend of growth genetic variation of seedling in trial)

Tabel 2. Analisis varian pertumbuhan semai $H$. macrophyllus umur 2,5 bulan (ANOVA for growth of seedling $H$. macrophyllus on 2.5 month old)

\begin{tabular}{lcc}
\hline $\begin{array}{c}\text { Sumber Keragaman } \\
\text { (Source of Variation) }\end{array}$ & d.b $(\boldsymbol{d} . \boldsymbol{f})$ & $\begin{array}{c}\text { Rerata Kuadrat } \\
\text { (Mean of Sqauares) }\end{array}$ \\
\hline Ulangan & 4 & 32,88 \\
Provenans & 6 & $10880,91^{(* *}$ \\
Famili (Provenans) & 105 & $615,50^{(* *}$ \\
Ulangan*Famili(Provenans) & 444 & $116,58^{(* *}$ \\
Error & 2.230 & 98,29 \\
\hline
\end{tabular}

Keterangan : $(* *=$ siginifikan pada level 0,01$)$

Tabel 2 menunjukkan bahwa pemilihan provenans/populasi maupun pemilihan famili untuk yang mempunyai pertumbuhan paling baik sangat penting dilakukan untuk mendapatkan benih unggul yang mempunyai pertumbuhan atau riap volume yang tinggi. Hal tersebut disebabkan olek karena provenans atau famili di dalam provenans mempunyai pengaruh terhadap pertumbuhan tinggi $H$. macrophyllus.

\section{Pembahasan}

Asal benih menyebabkan terjadinya perbedaan rerata tinggi antar populasi atau antar provenans pada bibit $H$. macrophyllus untuk setiap umur. Terjadinya perbedaan tersebut karena perbedaan lingkungan tanaman $H$. macrophyllus di populasi asal. Perbedaan lingkungan tersebut antara lain: suhu udara, curah hujan, ketinggian tempat, biodiversitas jenis, maupun kesuburan tanah. Selain perbedaan lingkungan di 7 populasi asal tersebut, maka perbedaan genotipe juga menyebabkan terjadinya perbedaan rerata populasi dari 7 populasi yang diuji. Populasi atau provenans Cipatujah-Sodong Hilir yang paling baik pertumbuhannya dalam uji tersebut menunjukkan bahwa asal benih dari populasi tersebut mempunyai kualitas pertumbuhan yang terbaik. Analisis kualitas provenans juga telah diteliti oleh Cheah and Plale (2012) sehubungan dengan berbagai aplikasi penggunaan populasi atau provenans yang terbaik.

Heritabilitas yang dihasilkan tergolong tinggi, hal tersebut menunjukkan bahwa faktor genetik 
sangat mempengaruhi pada keragaman tinggi bibit jenis H (Gambar 2). macrophyllus . Heritabilitas yang tinggi juga ditemukan pada penelitian jenis lainnya. Prasetyo dan Susanto (2015) telah memperoleh heritabilitas tinggi pohon yang tergolong tinggi yaitu 0,37 di uji keturunan ulin umur 5,5 tahun. Mashudi dan Baskorowati (2015) telah menemukan nilai heritabilitas individu yang tinggi pada Alstonia scholaris untuk diameter sebesar 0,44 dan tinggi pohon sebesar 0,53. Mashudi dan Susanto (2016) menemukan heritabiitas tinggi pohon sebesar 0,32 pada uji keturunan pulai umur 3 tahun.

Tren heritabitas individuyang naik turun sesuai umur, mengindikasikan bahwa pengaruh genetik terhadap tinggi bibit berubah-ubah besarnya sesuai umur pengamatan. Hal tersebut mengindikasikan bahwa faktor genetik pertumbuhan kinerjanya tidak tetap dari waktu ke waktu. Perubahan heritabilitas yang disebabkan oleh umur tanaman dapat dijelaskan adanya pengaruh alel epistasis dan interaksi gen dengan lingkungan yang secara komplek menyebabkan terjadinya perubahan heritabilitas bahkan heritabilitas yang hilang. Hal tersebut telah diteliti oleh Marian (2012) mengenai heritabiltas yang hilang. Perubahan heritabilitas juga ditemukan pada uji keturunan Falcataria moluccana di Cikampek pada umur 2 tahun dan 4 tahun oleh Susanto d.k.k.(2014).

Keragaman genetik bibit $H$. macrophyllus mengalami perubahan sesuai umur bibit $H$. macrophyllus. Pada awalnya keragaman genetik tinggi $H$. macrophyllus mengalami kenaikan, namun setelah umur 1,0 bulan keragaman genetik tinggi bibit mengalami penurunan (Gambar 3). Adanya penurunan keragaman genetik pertumbuhan di persemaian disebabkan oleh faktor lingkungan yang sangat berperan sebagai sumber keragaman. Hal serupa juga ditemukan oleh Baliuckas et al. (1999) pada penelitian di 6 populasi Prunus ditingkat persemaian yang menunjukkan adanya penurunan keragaman genetik pertumbuhan tinggi. Umur 1,5 bulan bibit $H$. macrophyllus mulai mengalami adanya interaksi antara genetik dan lingkungan (famili dengan ulangan), sehingga pada umur 1,5 bulan sampai dengan 2,5 bulan terjadi penurunan keragaman famili (genetik).
Keragaman tinggi pohon antar populasi maupun antar famili dalam populasi ditemukan pada bibit $H$. macrophyllus umur 2,5 bulan secara signifikan. Selain itu keragaman tinggi pohon bibit $H$. macrophyllus juga disebabkan oleh adanya interaksi antara ulangan dengan famili di dalam populasi (genetik dan lingkungan). Keragaman tinggi pohon $H$. macrophyllus di antara populasi maupun famili di dalam populasi secara signifikan juga ditemukan oleh Susanto (2016) pada umurumur sebelumnya. Adanya interaksi genetik dan lingkungan juga ditemukan oleh Setyaji (2013) pada penelitian uji keturunan Acacia mangium generasi ke dua di Sumatera dan Kalimantan

Berdasarkan nilai heritabilitas individu tinggi bibit yang tergolong tinggi maka jenis $H$. macrophyllus sangat penting untuk dimuliakan untuk meningkatkan riap volume. Riap volume mempunyai hubungan yang jelas dengan pertumbuhan tinggi pohon (diameter batang dan tinggi pohon). Program pemuliaan $H$. macrophyllus dapat dilaksanakan ke depan karena adanya keragaman genetik pohon $H$. macrophyllus yang cukup luas. Tahapan kegiatan pemuliaan $H$. macrophyllus antara lain dengan melakukan uji keturunan terhadap famili-famili yang telah diuji pada persemaian. Uji keturunan yang telah cukup umur, maka akan dilakukan evaluasi dengan mengkukur pertumbuhan maupun riap volume. Hasil pengukuran selanjutnya dianalisis parameter genetik untuk melakukan seleksi pohon. Pemuliaan tanaman sangat tergantung dari seleksi phenotipik, sehingga dikembangkan konsep baru dengan melakukan seleksi genom, namun hal tersebut sulit diterapkan (Jonas and De Koning, 2013). Beberapa peneliti yang melaukan penelitian tentang seleski genom antara lain : Iwata, Minamikawa, Kajiya-Kanegae, Ishimori, \& Hayashi (2016)such as genome-wide association studies (GWAS; Bassi, Bentley, Charmet, Ortiz, \& Crossa (2015); dan Grattapaglia (2014).

Seleksi pohon yang mudah diterapkan adalah dengan menghitung nilai pemuliaan (Breeding Value). Seleksi pohon berdasarakan nilai pemuliaan riap volume, maka hutan tanaman $H$. macrophyllus yang berasal dari kebun benih uji tersebut dapat diprediksi produktifitasnya pada tahap panen. 
Penggunaaan nilai pemuliaan banyak dilakukan di penelitian-penelitian pertanian. Varshney et.al. (2014) mengatakan bahwa teknologi NGS (Next Generation Sequencing) yang dikombinasikan dengan metode phenotip yang tepat maka dapat memprediski nilai pemuliaan dalam pertanian.

Hasil analisis keragaman genetik dipersemaian yang mengalami perubahan akibat adanya interaksi antara famili di dalam provenans dengan ulangan, maka hal tersebut sangat penting diperhatikan dalam melakukan pembangunan uji keturunan. Hal yang perlu diperhatikan adalah rancangan uji keturunan yang akan dibangun, karena faktor genetika telah berinteraksi dengan lingkungan. Rancangan yang telah memperhatikan adanya interaksi genetik dan lingkungan, maka benih unggul yang akan dihasilkan dapat mencerminkan kinerja genetik dan lingkungan. Kinerja interaksi genetik dan lingkungan banyak dipelajari oleh peneliti-peneliti, antara lain: Malosetti et al. (2013) telah menyampaikan serangkaian model untuk menggambarkan, menjelajahi, memahami, dan memprediksi interaksi genetik dan lingkungan. Feil and Fraga (2012) telah menyampaikan telaah mengenai faktor lingkungan memodulasi pembentukan dan modifikasi epigenetik yang dapat mempengaruhi ekspresi gen dan fenotip. Gagneur et al. (2013)causal intermediates between genotype and phenotype constitute valuable candidates for molecular intervention points that can be therapeutically targeted. Mapping genetic determinants of gene expression levels (also known as expression quantitative trait loci or eQTL studies menyampaikan bahwa keragaman genetik berdasarkan lingkungan sehingga efek phenotipik tergantung lingkungan. Burgueño et al. (2007) telah meneliti efek genotipe terhadap aditif dan aditif ke aditif dan interaksi aditif dengan lingkungan untuk mengindentifikasi efek aditif untuk digunakan dalam program perkawinan silang (crossing).

\section{Kesimpulan dan Saran}

\section{Simpulan}

Bahwa populasi $H$. macrophyllus yang diuji mempunyai tren pertumbuhan tinggi yang hampir sama untuk 7 populasi yang diuji. Jenis H. macrophyllus pada tingkat semai mempunyai keragaman pertumbuhan diantara populasi maupun antar famili di dalam populasi secara signifikan. Nilai estimasi heritabilitas tinggi bibit H. macrophyllus berubah-ubah seseuai waktu pengamatan. Keragaman genetik pertumbuhan bibit $H$. macrophyllus mulai umur 1,0 bulan mengalami penurunan sampai pengamatan terakhir (umur 2,5 bulan).

\section{Saran}

Penelitian dilanjutkan sampai pada tingkat uji keturunan yang akan dibangun di lapangan untuk diteliti dan ditambah parameter genetiknya sampai umur akhir daur jenis H. macrophyllus. Pada level umur pertumbuhan pada level uji keturunan di lapangan agar ditambah sifat-sifat yang diteliti antara lain: sifat kayu, diameter batang, kelurusan batang agar dapat menghasilkan benih unggul yang mempunyai riap volume yang tinggi dan kualitas kayu yang baik.

\section{Ucapan Terimakasih}

Terimaksih kami ucapkan kepada seluruh teman-teman tim kayu pertukangan (Dr. Liliana Baskorowati; Hamdan Atma A, MSc; Dedi Setiadi, MSc; Sugeng Pudjiono, MP) di Balai Besar Penelitian dan Pengembangan Bioteknologi dan Pemuliaan Tanaman Hutan-Yogyakarta yang membantu penelitian jenis $H$. macrophyllus . Kepada Bp Maman Sulaeman S.Hut, Bp Widodo, dan Ignatius Wenda yang membantu pekerjaan persemaian $H$. macrophyllus beserta pengamatan mulai dari awal sampai akhir.

\section{Dafatar Pusataka}

Baliuckas, V., Ekberg, I., Eriksson, G. and Norell, L. (1999) 'Genetic variation among and within populations of four Swedish hardwood species assessed in a nursery trial', Silvae Genetica, 48(1):17-25.

Bassi, F. M., Bentley, A. R., Charmet, G., Ortiz, R., \& Crossa, J. (2015). Breeding schemes for the 
implementation of genomic selection in wheat (Triticum spp.). Plant Science, 242, 23-36. https://doi.org/10.1016/j.plantsci.2015.08.021

Burgueño, J., Crossa, J., Cornelius, P. L., Trethowan, R., McLaren, G., \& Krishnamachari, A. (2007). Modeling additive ?? environment and additive ?? additive ?? environment using genetic covariances of relatives of wheat genotypes. Crop Science, 47(1), 311-320. https:// doi.org/10.2135/cropsci2006.09.0564

Cheah, Y. W., \& Plale, B. (2012). Provenance analysis: Towards quality provenance. In 2012 IEEE 8th International Conference on E-Science, e-Science 2012. https://doi.org/10.1109/ eScience.2012.6404480

Feil, R., \& Fraga, M. F. (2012). Epigenetics and the environment: emerging patterns and implications. Nature Reviews Genetics, 13(2), 97-109. https://doi.org/10.1038/nrg3142

Gagneur, J., Stegle, O., Zhu, C., Jakob, P., Tekkedil, M. M., Aiyar, R. S., ... Steinmetz, L. M. (2013). Genotype-Environment Interactions Reveal Causal Pathways That Mediate Genetic Effects on Phenotype. PLoS Genetics, 9(9). https://doi.org/10.1371/journal.pgen.1003803

Grattapaglia, D. (2014). Breeding Forest Trees by Genomic Selection: Current Progress and the Way Forward. Genomics of Plant Genetic Resources. https://doi.org/10.1007/978-94-007-7572-5

Iwata, H., Minamikawa, M. F., Kajiya-Kanegae, H., Ishimori, M., \& Hayashi, T. (2016). Genomicsassisted breeding in fruit trees. Breeding Science, 66(1), 100-15. https://doi.org/10.1270/ jsbbs.66.100

Jonas, E., \& De Koning, D. J. (2013). Does genomic selection have a future in plant breeding? Trends in Biotechnology. https://doi.org/10.1016/j.tibtech.2013.06.003

Malosetti, M., Ribaut, J. M., \& van Eeuwijk, F. A. (2013). The statistical analysis of multienvironment data: Modeling genotype-by-environment interaction and its genetic basis. Frontiers in Physiology, 4 MAR. https://doi.org/10.3389/fphys.2013.00044

Marian, A. J. (2012). Elements of "missing heritability." Current Opinions Cardiology, 27(3), 197201. https://doi.org/10.1097/HCO.0b013e328352707d

Mashudi dan Baskorowati, L. (2015). Estimasi Parameter Genetik pada Uji Keturunan Alstonia scholaris umur Dua Tahun di Gunungkidul, Yogyakarta. Jurnal Pemuliaan Tanaman Hutan $9(1): 1-11$.

Mashudi dan Susanto, M. (2016). Evaluasi Uji Keturunan Pulai Darat (Alstonia angustiloba Miq.) Umur Tiga Tahun Di Wonogiri, Jawa Tengah. Jurnal Pemuliaan Tanaman Hutan 10(2):8394.

Prasetyono dan Susanto, M. (2015). Variasi Sifat Pertumbuhan Ulin (Eusideroxylon zwageri T. et B.) Pada Uji Keturunan Di Bondowoso. Jurnal Wasian 2(2):79-86

Setyaji, T. (2013). Interaksi Famili Lokasi pada Uji Keturunan Generasi Kedua Acacia mangium di Sumatera dan Kalimantan. Jurnal Pemuliaan Tanaman Hutan, 7(1):41-52.

Suhaendah, E. dan Winara, A. (2015). Efektivitas Insektisida Hayati Terhadap Hama Tisuk (Hibiscus macrophyllus) Jenis Podagrica javana Secara In Vitro. Prosiding Seminar Nasional Agroforestry: 459-464.

Susanto, M. (2016). Genetic Variation of Warugunung (Hibiscus Macrophyllus) In Biodiversity Of Privatelly Owned Forest. Proceeding Seminar nasional biodiversitas VI Surabaya, 3 September 2016 "Biodiversitas untuk Pembangunan Berkelanjutan : Keanekaragaman hayati Indonesia Dan perannya dalam menunjang Kemandirian bangsa" Departemen Biologi Fakultas Sains Dan Teknologi Universitas Airlangga. p:403-411. 
Susanto, M., Baskorowati, L. Dan Setiadi, D. (2014). Estimasi Peningkatan Genetik Falcataria moluccana Di Cikampek Jawa Barat. Jurnal Penelitian Hutan Tanaman. 11(2):65-76.

Varshney, R. K., Terauchi, R., \& McCouch, S. R. (2014). Harvesting the Promising Fruits of Genomics: Applying Genome Sequencing Technologies to Crop Breeding. PLoS Biology, 12(6), 1-8. https://doi.org/10.1371/journal.pbio.1001883

Wardani, M. (2007). Waru Gunung (Hibiscus macrophyllus Roxb ex Hornem) dan Pemanfaatanya di Kabupaten Ciamis, Jawa Barat. Info Hutan Vol. 4(4):391-397. 